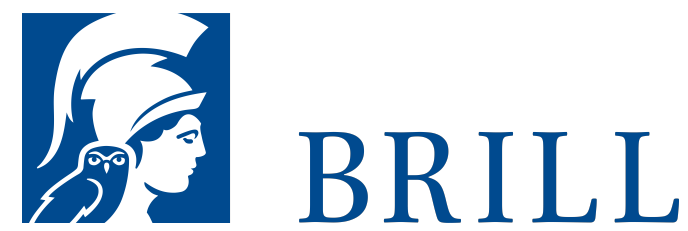

\title{
Kursk 1943
}

Die größte Schlacht des Zweiten Weltkriegs. 2., durchgesehene Auflage

\section{Author: Roman Töppel}

Die Panzerschlacht bei Kursk im Sommer 1943 war eine der größten Schlachten der Kriegsgeschichte, an der etwa drei Millionen Soldaten mit mehr als 10.00o Panzern und Selbstfahrlafetten sowie 8.ooo Flugzeugen teilnahmen. Obwohl Kursk bis heute als eine der Entscheidungsschlachten des Zweiten Weltkriegs gilt und schon zahlreiche Bücher darüber geschrieben wurden, gibt es über zentrale Entscheidungen im Vorfeld der Schlacht und über die Kämpfe im Sommer 1943 erstaunlich viele falsche Informationen und Legenden. Roman Töppel beschreibt in seiner Studie vor allem Entwicklungen und Begebenheiten der Kursker Schlacht, die bislang kaum bekannt sind oder denen nur wenig Beachtung geschenkt wurde. Er präsentiert dem Leser neue, zum Teil überraschende Forschungsergebnisse und setzt damit der noch heute anhaltenden Legendenbildung um diese Schlacht gründlich recherchierte Fakten entgegen.

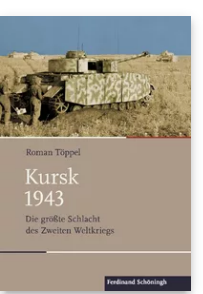

Pages: ca. 289 Seiten, $24 \mathrm{~s} / \mathrm{w}$ Abb.

Language:

German

Subjects:

Modern History, History

Publisher: Brill | Schöningh

Series:

Schlachten -

Stationen der Weltgeschichte

E-Book (PDF)

Released online: 13 Mar 2017

ISBN: 978-3657-78187-4 Hardback Publication date: 29 Sep 2017 ISBN: 978-3506-78867-2 List price 
Roman Töppel ist promovierter Historiker und gilt als führender Experte für die Schlacht von Kursk.

For more information see brill.com

\author{
Order information: Order online at brill.com \\ +44330 333 o049 | customerservices@brill.com \\ Submission information: brill.com/authors
}

Titles published by Brill | Fink, Brill | mentis or Brill| Schöningh:

+49(o)71 5413279216 | brill@brocom.de 